\title{
Article \\ Evaluation of the Program Subsidizing Prosumer Photovoltaic Sources in Poland
}

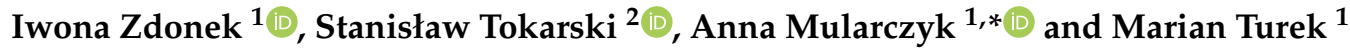 \\ 1 Department of Economy and Informatics, Faculty of Organization and Management, Silesian University of \\ Technology, Akademicka 2A, 44-100 Gliwice, Poland; iwona.zdonek@polsl.pl (I.Z.); \\ marian.czeslaw.turek@polsl.pl (M.T.) \\ 2 Central Mining Institute, Plac Gwarków 1, 40-166 Katowice, Poland; stokarski@gig.eu \\ * Correspondence: anna.mularczyk@polsl.pl
}

Citation: Zdonek, I.; Tokarski, S.; Mularczyk, A.; Turek, M. Evaluation of the Program Subsidizing Prosumer Photovoltaic Sources in Poland. Energies 2022, 15, 846. https:// doi.org/10.3390/en15030846

Academic Editor: Ignacio Mauleón

Received: 9 November 2021

Accepted: 17 January 2022

Published: 24 January 2022

Publisher's Note: MDPI stays neutral with regard to jurisdictional claims in published maps and institutional affiliations.

Copyright: (C) 2022 by the authors. Licensee MDPI, Basel, Switzerland. This article is an open access article distributed under the terms and conditions of the Creative Commons Attribution (CC BY) license (https:// creativecommons.org/licenses/by/ $4.0 /)$.

\begin{abstract}
This article attempts to evaluate the My Electricity program concerning increasing renewable energy production in photovoltaic (PV) prosumer sources (PV micro-installations) in Poland. The assessment is made from the perspective of beneficiaries, business, and local community. One may also find an answer to the question of how this program should be modified so that it continues to support the development of PV systems in Poland. Moreover, how Poles assess the PV technology, in terms of the safety of its users and its impact on the environment, is studied. For this purpose, there was exploratory, qualitative, and quantitative research conducted. Twelve case studies were used as well as online questionnaires conducted on prosumers who used the My Electricity program to install PV micro-installations (57 respondents). By means of interviews, there was a confrontation of their point of view with the opinions of seven skeptics of such installations. Moreover, five experts from the energy industry and politicians involved in the transformation of the energy system were interviewed in order to balance the enthusiastic opinions of prosumers and the skeptical views of objectors to home PV systems. The results of our research indicate that the program is rated very well by enthusiasts of PV systems, although they emphasize the high investment costs and the lack of solutions supporting energy storage. Experts point out that the power grid in Poland is not prepared for such an immediate increase in prosumer PV systems, and they suggest more care in solving this problem.
\end{abstract}

Keywords: photovoltaic installations; PV; subsidies for photovoltaic installations; My Electricity program; development forecasts for prosumer photovoltaic installations; supporters; objectors of PV micro-installations

\section{Introduction}

On 2 February 2021, the Council of Ministers approved the document entitled "Polityka energetyczna Polski do 2040 r." ("Energy Policy of Poland until 2040": PEP2040). In a notice posted on the government website [1], it was stated that this document is to constitute "a clear vision of Poland's energy transformation strategy". In the coming years, meeting the economy's demand for power and electricity will to a large extent continue to be provided by the coal-based energy sector, but it is assumed that its share in the energy generation structure will gradually decline. Renewable energy sources (RES) are to play an increasingly important role in the production of electricity; their level in the national structure should be at least $32 \%$ in 2030 , which is primarily to be achieved through the development of PV systems and offshore wind farms. The goal of one of the pillars of PEP2040, entitled "Zeroemisyjny system energetyczny" ("Zero emission energy system"), is to expand the electricity generation and grid infrastructure. In Poland, where hard coal is still widely used as a fuel, all activities aimed at eliminating the phenomenon of the so-called low emissions, primarily responsible for high air pollution, play a unique role. The studies summarizing the research conducted in this area [2-8] demonstrate a 
number of technical and economic aspects of such activities. In July 2021, the European Commission published the "Fit for 55" package [9], which contains many changes to the existing regulations and introduces the new target of reducing emissions by $55 \%$ in 2030 . The package includes, among others, a proposal to increase the share of renewable energy in gross final energy consumption to $40 \%$ in 2030. Adoption of an increased RES target will quicken investments in new, non-emission sources in the generation sector. These investments also apply to Poland, especially since there are analyses related to delays in the implementation of investment programs in the Polish energy sector [10].

In PEP2040, it is assumed that there will be a significant increase to 5-7 GW in 2030 and 10-16 GW in 2040 in the capacity of PV systems. To encourage citizens to install PV systems on a large scale, the government initiated the My Electricity program in 2019, according to which private electricity consumers received subsidies up to $50 \%$ of the value of the PV installation but not more than PLN 5000 (1085 EUR). This program, so far carried out in three editions, has been met with great interest by individual users. It is estimated that the total capacity of the newly built installations amounted to almost $2.5 \mathrm{GW}$, and on sunny days it covers about $5 \%$ of the peak domestic demand for power. The third edition of the program began in July 2021. Along with the introduction of the My Electricity program, supporting the expansion of home PV systems, research related to it began [11,12]. It showed the dependence of investments in home PV systems on factors such as population and solar conditions in individual Polish provinces [11]. Moreover, it was proven that the funds provided under the grant do not optimally distribute relatively to the effects generated by the My Electricity program [12]. Therefore, there is a research gap that needs to be filled. The presented work conducts qualitative and quantitative exploratory studies that will show the assessment of the My Electricity program not only from the perspective of PV micro-installation enthusiasts but also its skeptics and experts, with technical and regulatory experts in energy system management.

Thus, the main goal of this article is to answer the following research questions:

- RQ1: What is the assessment of the effectiveness of the My Electricity program in terms of increasing the production of renewable energy in prosumer sources (the perspective of beneficiaries, legislators, business, local community)?

- $\quad$ RQ2: In what directions should the My Electricity program be modified (amount of support, formal procedures, functionality: energy storage, heating, electromobility)?

- RQ3: How is PV technology perceived in terms of the safety of its users and its impact on the environment?

\section{Literature Review}

\subsection{The My Electricity Program as a Subject of Empirical Research}

The My Electricity program is a new instrument, on the current scale in Poland, dedicated to supporting the development of prosumer energy and the development of the PV micro-installations segment $[13,14]$. It was created, inter alia, in response to Specific Objective 6, "Development of renewable energy sources", of PEP2040 [1]. The first two editions lasted from 30 August 2019 until 6 December 2020. The third edition, entitled My Electricity 3.0, started on 1 July 2021, and it will run until 20 December 2021. The next edition of the program is also planned with new technologies, which, in addition to PV systems, will also be covered by financial support. Subsidizing parts, such as the construction of charging points for electric cars and the installation of intelligent energy management systems at home, is being considered. Further improvements to the program are also being developed to strengthen the energy sector's local dimension by incentivizing beneficiaries to use hybrid solutions, combining non-controllable RES generation sources with energy storage. The program's main goal is to increase electricity production from PV micro-installations. Funding applies to PV system installations with 2-10 kWh capacity. Currently, funding is in the form of a grant covering up to $50 \%$ of the eligible costs of the micro-installation included in the project but not more than PLN 3000 (651 EUR) per project (in the My Electricity 3.0 edition; previously, the maximum amount of funding was PLN 5000 (1085 EUR)). The funding 
applies to installations not completed before 23 July 2019. However, the project must be completed before the date of submission of the funding application. The application may be submitted by natural persons generating electricity for their own needs who have already concluded a comprehensive agreement with the power grid owner regulating the issues related to the introduction of electricity generated in micro-installations to the grid. As of the end of 2020, over 266,000 applications for funding were submitted; the budget allocated to the program was significantly exceeded (initially PLN 1 billion (216,919,739 EUR), increased by PLN 100 million (21,691,974 EUR); PLN 200 million (43,383,948 EUR) is still missing). If the pool of money is not increased, the funding rules will be changed. The purchase price of the installation will determine its amount. The cheaper the installation per $1 \mathrm{kWh}$ of installed capacity, the more points the beneficiary will receive during the assessment. The maximum number of points (four), and, thus, a priority in the payment of subsidies, will be available to those who paid below PLN 6000/kW (1302 EUR) for the installation; three points will be awarded to those who paid from PLN 6000 to PLN 6500/kW (1302-1410 EUR), two points for those who spent PLN 6500-7000/kW (1410-1518 EUR), and the lowest score (one point) to those who paid over PLN 7000/kW (1518 EUR) for the installation. The sources of financing include funds from the state budget and the European Union. The amount of funding in the second edition is PLN 1.1 billion (216,919,739 EUR) (shortfall of PLN 200 million (43,383,947 EUR), increased to PLN 1155 million (250,542 EUR)) and in the third edition, PLN 534 million (115,835,140 EUR). In mid-2021, the capacity of PV power plants installed in the national power system exceeded $4.3 \mathrm{GW}$.

\subsection{Technical Limitations of PV System Development in Poland}

Electricity production by PV micro-installations is changing the traditional way of operating the distribution grid. During hours of intense sunlight, prosumer micro-installations generate excess electricity and send it to local consumers, increasing the voltage in lowvoltage networks and affecting the automation of power stations and transformers. In periods with low insolation, electricity is sent in the opposite direction, from the station to the prosumer-consumer, causing undesirable voltage reduction in dispersed systems of rural networks. The effects of voltage variations must be considered in the electrical network's planning and safe and efficient operation. The distribution system operator is responsible for this. Thus, installing PV microsystems in low-voltage grids changes the operating characteristics of these grids from changing demand to variable demand and supply. If the total power supplied by the home PV system to the grid exceeds local consumption, the excess energy causes a reverse power flow to the medium-voltage system. The low-voltage distribution network area then functions as a power plant. A small amount of distributed energy production by PV micro-installations may be acceptable or beneficial to the grid. More significant amounts, in turn, can negatively affect the distribution network $[15,16]$. Due to the increase in the number of PV micro-installations found in various countries, research is being conducted on how to increase the PV system adoption capacity in distribution grids $[17,18]$. According to study [19], several technical solutions are available, including grid expansion, voltage regulation on transformer taps, or active demand and supply management.

\subsection{Determinants of Decisions on Investments in PV Micro-Installations}

Analysis of the literature shows that many variables influence the decision to install PV micro-installations. Economic factors are the priority [20,21]. Works [22,23] indicate that they include the level of income and accumulated capital. That means that people with high incomes, and those with accumulated capital, will be able to cover the costs of PV microinstallations. Installation costs also belong to the group of economic factors. However, their height negatively affects the installation of home PV systems [24]. Research [25,26] shows that high electricity costs also positively impact the decision to install PV microinstallations. Besides that, homeowners are more likely than tenants to invest in PV systems. Subsidies also have a positive impact on the decision to install PV systems $[20,24,27-34]$. 
There are studies that show that economic factors are often used to develop the PV market. An example is given in [35], in which, to develop the PV market, it had to go through three stages: (1) market preparation, (2) market formation, and (3) market expansion. The following policies support market preparation and formation: net metering standards, interconnection standards, PPA standards, RPS, and solar carve-outs. Market expansion is supported by state-sponsored direct monetary incentives, sales tax reliefs, property tax reliefs, income tax reliefs, and feed-in tariffs (FIT) [36]. In Poland, an auction system is currently used for larger RES sources and prosumers-net metering, with a deduction of $20 \%$ or $30 \%$ of energy fed into the grid.

The second group of factors is the characteristics of households. This group includes, for example, the level of education of its members. Higher education or technical education (not necessarily higher) is positively correlated with the decision to build a PV system [37,38]. Since technical education is rather the domain of men, the presence of men in the household also influences the use of this technology [37]. Moreover, studies [39] show that smaller families may have a higher income and, thus, are more likely to decide to install PV systems.

The third group of factors is the characteristics of the surrounding buildings. For example, population density is negatively correlated with PV system installations, and so people in less populated areas are more likely to opt for PV systems [40]. Interestingly, studies [40] show that higher house density affects PV system installations. That means that the higher density of houses allows better use of sunlight. Moreover, owners of detached homes are more likely to decide on PV systems than residents of terraced houses. It is most likely related to the roof surface [39]. In addition, owners of large houses (with more rooms) are also more likely to adopt PV systems, due to the high energy demand and savings they can generate with PV systems [41].

The fourth group is environmental factors. These include ecological awareness, positively correlated with the decision to install a PV system [24], the share of hybrid or electric cars purchased among the total number of vehicles [38], and the level of pollution in a given region [39].

The last group consists of factors from the range of peer effects. They mean that the more PV systems are installed in the region, the more willingly subsequent homeowners use them. This is explained by social interactions between the residents of a given region [25,37,42-44].

The multitude of factors influencing the acceptance and willingness to install PV systems caused the need to group them more precisely. This was achieved in the work [45]. The authors of this paper provide three main groups of factors for the acceptance of PV systems. They are called individual, social, and information predictors. Individual predictors include personality, environmental, and personal values, attitude towards financial and technical aspects, general attitudes, and perceived risk. Social predictors contain education, age, gender, income, race, ethnicity, culture, family structure, house characteristics, socioeconomics, and socio-political variables. Information predictors involve financial, technical, and common knowledge.

\section{Materials and Methods}

\subsection{Choosing a Research Method}

To answer the questions posed in the article, we used research methods. The basic categories of questions begin with: "Who?", "What?", "How?", and "Why?". Since the research questions posed in the previous chapter are exploratory in nature, it was decided to use the case study method combined with interviews and the online questionnaire. The aim of finding answers to the research questions is to develop assumptions and hypotheses for further verification.

Various research methods can serve the purposes of exploration, for instance, statistical research on economic incentives for the expansion of micro-installations or surveys on the potential benefits of various categories of stimuli, not only economical. However, due to the complexity of the issue under study, it was decided to investigate the broadest possible range of problems related to the development of micro-installations with the examined 
My Electricity program. Questions such as "How many beneficiaries of the program were there?", "How have they benefited?", "How often were the various benefits obtained?" would not require a case study. However, a case study should be opted for when necessary to obtain the answer to the question, "How does this program work and/or why is it or not or will it be effective?", just the same as any other type of question that begins with "What?", "Who?", or "Where?" (or their derivative, "How many?") would encourage the carrying out of surveys and statistical analyses. These methods can be used when the goal of determining the scale of the occurrence of the phenomenon entitled "What is the importance of solar PV panel installations in the structure of energy generation?" is set. The questions "How?" and "Why?" are more exploratory, encouraging case studies during research. When posing these types of questions, the frequency or scope of the phenomenon under study is analyzed and the operational dependencies that require it to be traced over time.

To summarize, the nature of the research questions required a case study combined with interviews and the questionnaire conducted on a diverse group of respondents as a research method.

\subsection{Research Sample}

The research was performed on a sample of 81 people. Twelve different home PV installations subsidized by the My Electricity program were examined. These cases covered four provinces (Silesia, Lesser Poland, Masovia, Lodzkie), including those with the most polluted air. The study consisted of online interviews with the owners of these installations. At the same time, quantitative research was carried out using an online questionnaire. Data from 57 people who installed a PV system and used the My Electricity program were collected. Additionally, online interviews were conducted with 7 objectors to this type of installation. According to the research [44], a group of skeptics was selected. It was intentionally made in such a way as to meet the criteria of people who can afford to invest in home PV systems and, therefore, meet the economic standards. The group of skeptics consisted of people who had a permanent source of income in the form of a permanent job or retirement pension or were self-employed ( 3 people). This group was diverse in terms of age and education. However, considering the research in [44], it was ensured that the majority of this group were people with technical education, favoring decisions about installing PV microsystem technology. In order to balance the views of PV supporters and skeptics, 5 experts were interviewed. The following experts were selected: managers in electricity generation and distribution companies, energy consumers, energy advisors, and practitioners from universities. The research sample is presented in Table 1 (the quantitative results can be seen in Table S1).

Table 1. Research sample.

\begin{tabular}{cccc}
\hline Type of Research & \multicolumn{2}{c}{ Type of Respondents } & Type of Interaction \\
\hline \multirow{2}{*}{ Qualitative research } & Enthusiasts & 12 & Interviews conducted \\
& Skeptics & 7 & via instant messaging \\
& Experts & 5 & Online survey \\
\hline \multirow{2}{*}{ Quantitative research } & Enthusiasts & 57 & \\
\hline
\end{tabular}

Source: own study.

\subsection{Collecting Data}

Thus, the research procedure included both the qualitative and quantitative research stages. In the qualitative research stage, the data were recorded interviews conducted via video conferences using instant messaging or telephone. During interviews with the group of respondents of home PV installations owners, questions that were developed based on the generalized technology acceptance theory model [46] were asked. Therefore, questions concerned the expected benefits of home PV systems, the expected effort associated with its installation, favorable conditions during its installation, social impact, and the operation 
of PV micro-installations. In the group of questions relating to the expected benefits, there were questions regarding the benefits of the installation, the purpose of its installation, the method of determining its power, plans for further use of green electricity, and satisfaction with the received grant. In the group of questions regarding the expected effort, there were questions about problems related to the installation, connection to the grid, maintenance of installations, concerns, and plans for disposal of solar PV panels. In the group of questions regarding the social impact, the following questions were asked: who or what suggested the idea about investing in PV systems, the decisive moment of making that decision, the date of installation, the perception of the facility by the immediate surroundings. In the group of questions regarding favorable conditions, questions were asked: whether it was challenging to fill in the application for the My Electricity program and to find a company that would install a PV microsystem; and whether the respondent was satisfied with the way the application was handled and with the installation company. In the group of questions about its operation, questions were asked about assessing the My Electricity program, the PV microsystem installation, and PV technology. Respondents from the skeptical group were asked an open-ended question about concerns about installing home PV systems. In turn, the expert group was asked questions regarding assessing the probable expansion of PV systems as distributed prosumer sources in the context of the power system's stability and control of these sources' operation. In addition, questions were asked about the risks associated with the installation of PV installations on the roofs or façades of buildings. They were also asked about the probability of introducing the obligation to equip every new home with PV installations and whether the disposal of PV panels could get in the way of developing this technology. Finally, it was asked how long the Polish state should support the development of prosumer PV systems.

In the qualitative research stage, data using an online questionnaire were collected. Similar groups of questions were kept as in the interviews with PV enthusiasts. In the group of questions about the expected benefits, 4 questions were asked; in the group of inquiries related to the expected effort-2; in the group of questions about social impact-2; in the group of favorable conditions -1 ; in the group of use -4 questions. The answers to the questions were measured on the nominal scales (questions requiring single or multiple choice) and on the 5-point Likert scale (questions requiring the evaluation of a given statement).

\subsection{Data Analysis}

The interviews were recorded, and so their analysis was based on their playback. Two examiners analyzed them in order to minimize the risk of biased interpretation. During the research, the answers given by prosumers were recorded in tables, thus obtaining the following sets: benefits from PV systems; the effort put into its installation and connection to the grid; social impact; conditions that favor its installation. The same was done in the case of the analysis of data collected during interviews with skeptics and experts. The mean was calculated if an answer was given on a numerical scale (e.g., 1 to 5 for prosumers or 1 to 10 for experts). Quite a few sets of responses were obtained more than once. In this case, they were grouped into factors based on topic consistency. The survey results were analyzed using data visualization on bar and boxplot charts. In this way, the distribution of responses was investigated. To compare the answers given on the Likert scale in groups, the non-parametric Mann-Whitney test for independent samples was used.

\section{Results}

\subsection{Enthusiasm about Prosumer PV Installations}

\section{Expected benefits}

Qualitative research results

The benefits of home PV systems indicated by the respondents can be divided into four categories: economic, environmental, energy security, and others (Table 2). Economic benefits were usually listed first. These mainly included long-term benefits, such as lower electricity bills, and short-term benefits typically associated with subsidies, such as tax 
relief or funding of a PV investment with subsidies from the My Electricity program. Environmental benefits, such as environmental protection, ecological energy generation, reduction of $\mathrm{CO}_{2}$, and other harmful substance emissions, usually appeared in second place. Like other benefits, the surveyed prosumers indicated the ease and speed of a PV micro-installation, its maintenance-free operation, and the better appearance of this kind of installation compared to wind installations. Moreover, they pointed to future possibilities, such as adding additional (currently unused) energy consumers, the possibility of producing electricity on one's own, and contributing to the transformation of the Polish energy system.

Table 2. Benefits of a PV micro-installation $(n=12)$.

\begin{tabular}{lc}
\hline \multicolumn{1}{c}{ Benefits } & \multicolumn{1}{c}{ Group of Factors } \\
\hline $\begin{array}{l}\text { Lower electricity bills } \\
\text { The grant from the My Electricity program } \\
\text { Tax relief }\end{array}$ & $\begin{array}{c}\text { Economic benefits } \\
\text { (Primary investment motivators) }\end{array}$ \\
\hline $\begin{array}{l}\text { Source of green energy } \\
\text { Reduction of } \mathrm{CO}_{2} \text { emissions }\end{array}$ & $\begin{array}{c}\text { Environmental benefits } \\
\text { Following ecological trends related to environmental } \\
\text { protection }\end{array}$ \\
Ecological energy production & (Secondary investment motivators) \\
\hline $\begin{array}{l}\text { Possibility of connecting other electric equipment in } \\
\text { the future (e.g., car chargers, heat pumps, saunas) } \\
\text { Possibility to produce own electricity } \\
\text { Transformation of the Polish energy system }\end{array}$ & Energy security \\
\hline $\begin{array}{l}\text { Ease and speed of installation } \\
\text { Maintenance-free operation of the installation } \\
\text { Greater installation appearance compared to that of } \\
\text { wind installations }\end{array}$ & Other benefits \\
\hline Source: own study. &
\end{tabular}

The My Electricity program and the prospect of tax relief were indicated as short-term factors stimulating the decision to invest in home PV systems. The respondents pointed to the economic outlook related to lower electricity bills as the main factor for investment. Some prosumers also pointed out that their decision was primarily ecological and defined it as following the trend related to environmental protection. It should also be noted that all surveyed prosumers presented their decisions on the installation as a long-term, rational process based on profit and loss, preceded by conversations with friends who had already installed a PV micro-installation or friends with experts in the energy industry.

Most of the tested installations were designed to cover the electricity demand of equipment installed in the house. Therefore, the installation process was preceded by energy balance analyses (performed by representatives of installation companies; such analyses were often used as an element of marketing used by companies dealing with PV system installations). Among the cases studied, there were also two under-sized installations. These cases were related to heating the house with a heat pump, with the simultaneous lack of technical conditions to install a higher number of PV panels (lack of space on roof).

Quantitative research results

In the researched survey, the respondents and the interviewees were asked about the sources underlying the decision to invest in PV, asking them to define the importance of economic and ecological motives on a scale of 1-5 (Figure 1). Economic motives clearly prevailed (average grade: 4.1 ; coefficient of variation: $25 \%$ ) over ecological motives (average: 3.2, coefficient of variation: 43\%). Both ratings were significantly different (Mann-Whitney test: $p<0.001$ ). 


\section{Expected benefits of PV}

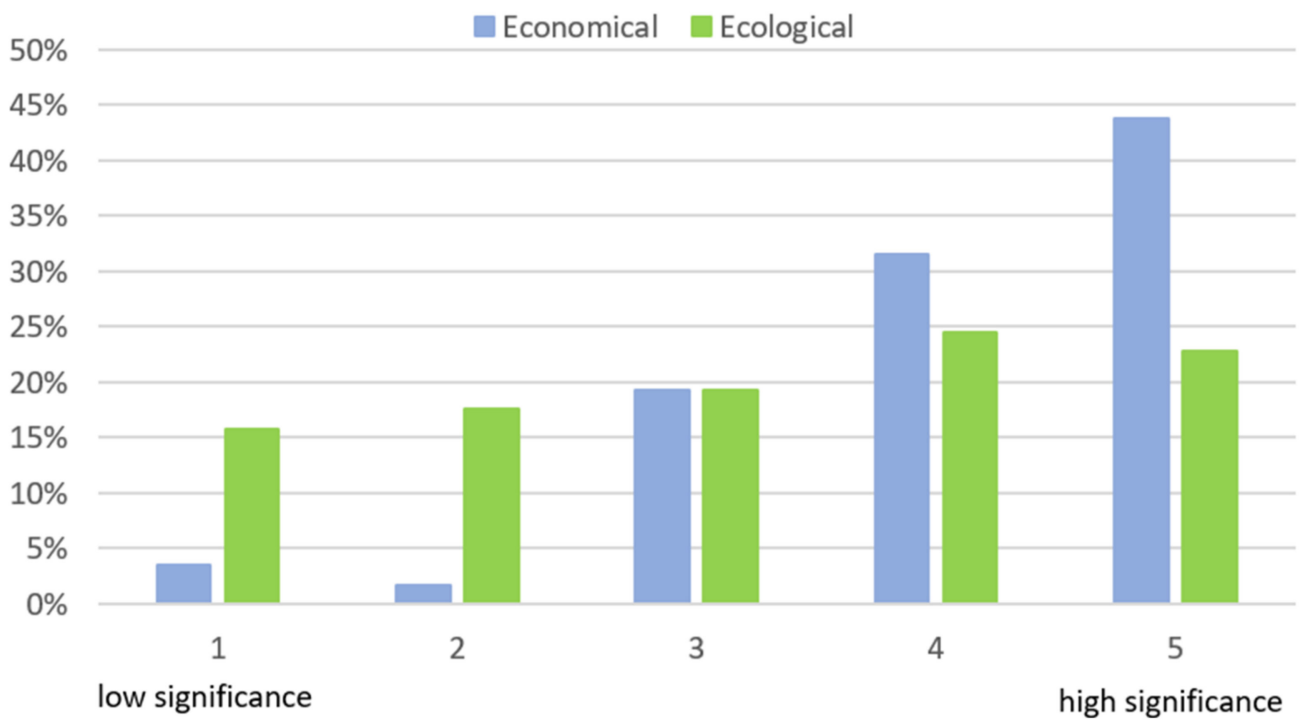

Figure 1. Expected benefits of a PV installation $(n=57)$. Source: own study.

On the other hand, when asked if the decision to invest was made for one of three reasons (only one answer could have been given), $58 \%$ of the respondents confirmed that their goal was to minimize the cost of electricity bills, and this was a decision independent of the My Electricity program. Moreover, a third of respondents linked this decision to introducing the program. In this case, only $5 \%$ of the respondents indicated ecological reasons as the most important, regardless of the My Electricity program. In the other option, the following reasons were given: (1) investment of funds (which is also an economic reason), and (2) advice of a friend (Figure 2).

\section{Reasons for the decision to build a photovoltaic installation}

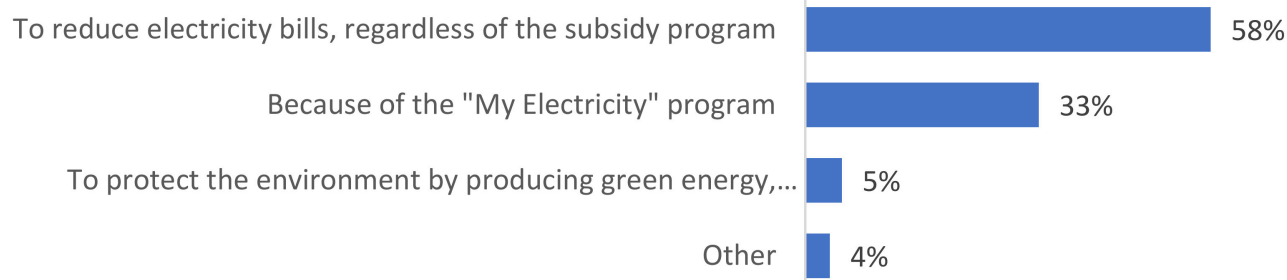

Figure 2. Main reason for PV installation $(n=57)$. Source: own study.

The respondents were then asked whether if it was possible to extend the installation scope with additional elements for which funding could be obtained and what devices they would choose. As many as $56 \%$ declared their willingness to purchase batteries for charging and storing electricity at home; $16 \%$ would invest in a domestic hot water storage tank heated during the day; and 11\% would install an electric car charger (Figure 3). 


\section{Devices declared provided a subsidy}

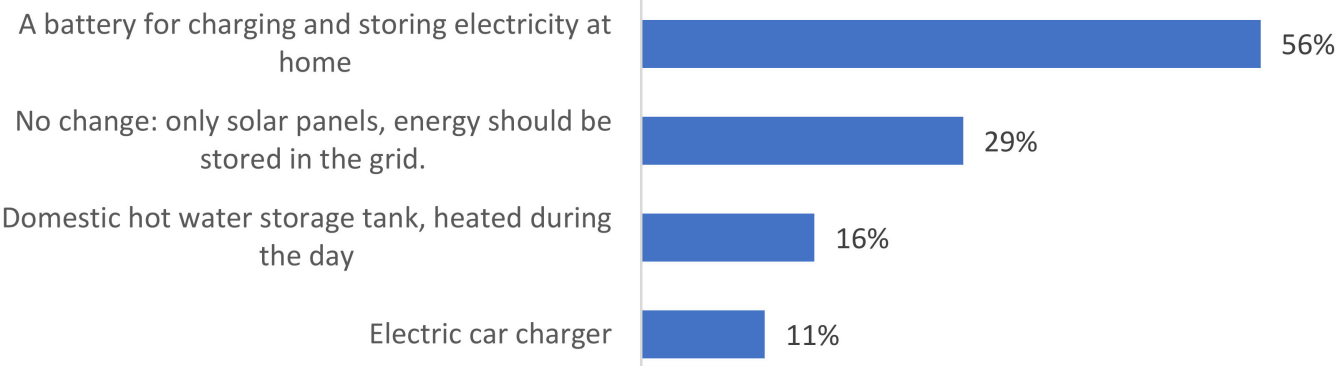

Figure 3. Preferred additional devices for obtaining funding $(n=57)$. Source: own study.

\section{Expected effort}

Qualitative research results

The interviews revealed a few components determining the financial effort (Table 3). In the studied cases, the investment in a PV micro-installation was defined as an average financial effort (installations with a capacity of less than $8 \mathrm{kWp}$ ) or a considerable financial effort (installations with more than $8 \mathrm{kWp}$ ). In all investigated cases, it was found that finding companies that carry out PV micro-installations was not complicated. Typically, such companies were recommended by friends (nine cases), in one case by a distribution company, and in two cases, the respondents found the company on the market. All respondents stated that the installation process was carried out very smoothly. The procedure of connecting PV micro-installations to the power grid was similarly highly rated. Therefore, it can be concluded that the respondents considered the effort put into installing home PV technology as low. The effort put into learning to operate this technology was similarly assessed. Everyone found it easy to use (as it was maintenance-free). The inverter interface and electronic software apps for monitoring the energy produced were very interesting. Most respondents initially checked the amount of electricity produced every day, and with time this frequency dropped to once or twice a week. PV micro-installations have been assessed as fault-free. The only things that surprised the respondents were the inverter occasionally turning off and the temporary lack of electricity production. In none of the cases studied did the respondents identify the effort involved in disposing of the panels and the inverter. They determined that the technology was too new to even think about that. However, they predicted that system solutions like those currently in force for household appliances and audio/video devices would be created.

Table 3. Investors' effort in a PV micro-installation $(n=12)$.

\begin{tabular}{cc}
\hline Effort & Amount \\
\hline Financial cost & Average for small installations, high for large installations \\
Installation & Low effort \\
Learning to operate & Low effort \\
Disposal & An unknown amount of effort \\
\hline
\end{tabular}

Source: own study.

\section{Quantitative research results}

In the survey research, the respondents were asked about the quality assessment of the construction process and the quality of the delivered devices (Figure 4). Seventy-nine percent declared no objections, while $7 \%$ claimed that they had to wait a long time for the installation or complaint process. Nevertheless, $7 \%$ were not interested in installation problems, and $7 \%$ did the installation themselves. 


\section{The assessment of the assembly process and the quality of the delivered devices}

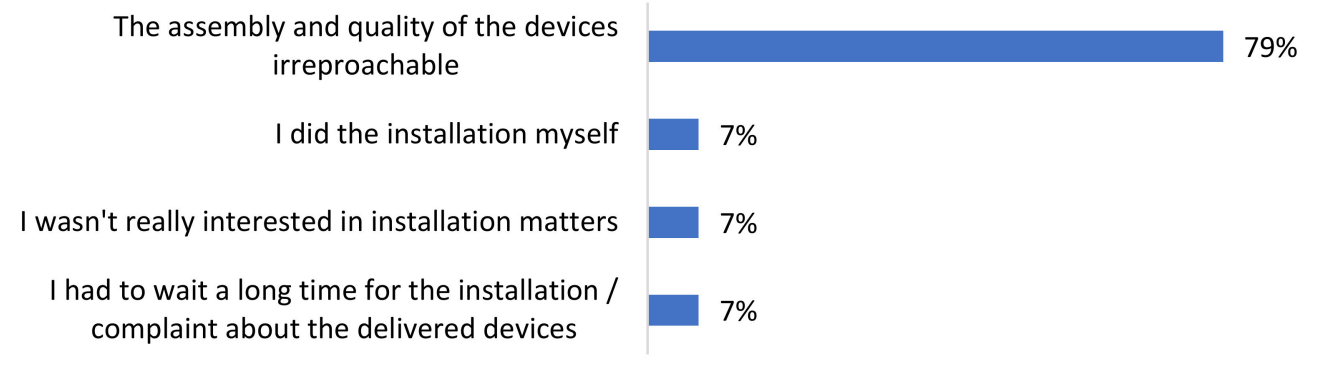

Figure 4. Answers to questions about the evaluation of PV assembly ( $n=57)$. Source: own study.

Subsequently, the respondents were asked about how the connection of PV to the power grid proceeded. Seventy-seven percent were satisfied with the connection process, while $19 \%$ declared that the connection process took a long time or additional interventions were necessary. Moreover, $4 \%$ claimed that the energy company demanded additional modifications to the power connection (Figure 5).

\section{The assessment of the connection of the PV installation to the power grid}

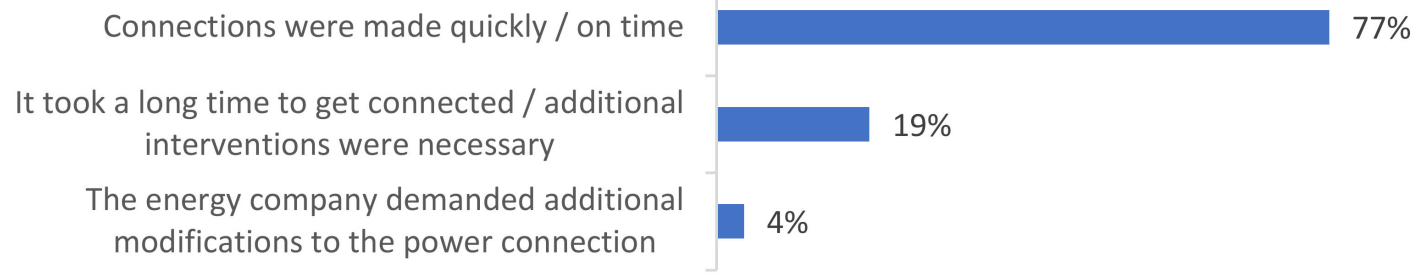

Figure 5. Answers to questions about connecting the PV installation to the power grid $(n=57)$. Source: own study.

\section{Social influence}

Qualitative research results

When deciding to install PV panels, the respondents largely considered the opinion of friends (including neighbors; Table 4), especially those pointing out economic benefits (four cases). However, when deciding for ecological reasons (three cases), the practices observed in other countries (Finland, Czech Republic) were also suggested. In one case, the decisions were influenced by advertisements and various offers from installation companies. However, they referred to a more significant impact of their own (economic) analyses than following friends' opinions in four cases. The financial aspect (grant from the My Electricity program, limited time and budget, the prospect of rising energy prices) played a crucial role in deciding to start an investment; five cases were in 2019 and the rest in 2020.

The respondents did not associate the installation of PV panels with prestige. It was argued that they are not always visible and that there are many such installations in the area. However, as pointed out, an important aspect was following modernity and ecology, reducing the negative impact on the environment, and rational behavior in terms of energy costs.

There were no questions directly related to social impact issues in the analyzed online questionnaire. Nevertheless, in the responses to the question about the reasons for installing a PV plant, there was the answer "Friend's advice" (1.7\%; Figure 2). That caused the need to include questions of this category in interviews and future surveys. 
Table 4. Social impact on making decisions about micro-installations $(n=12)$.

\begin{tabular}{lc}
\hline \multicolumn{1}{c}{ Social Influence } & Group of Factors \\
\hline $\begin{array}{l}\text { Recommended by other PV system users } \\
\begin{array}{l}\text { Observation of behavior in the neighborhood and } \\
\text { conversation (neighbors) }\end{array}\end{array}$ & $\begin{array}{l}\text { Opinions of friends } \\
\text { (Economic reasons) }\end{array}$ \\
\hline $\begin{array}{l}\text { Observation of behavior in other countries } \\
\text { The trend towards zero-emission energy production }\end{array}$ & $\begin{array}{c}\text { Ecological behavior } \\
\text { (Environmental awareness) }\end{array}$ \\
\hline $\begin{array}{l}\text { Phones with installation suggestions } \\
\text { Lower installation prices }\end{array}$ & $\begin{array}{c}\text { Advertising of installation companies } \\
\text { (marketing) }\end{array}$ \\
\hline $\begin{array}{l}\text { Increasing electricity prices } \\
\text { The grant from the My Electricity program/tax relief }\end{array}$ & $\begin{array}{c}\text { Other } \\
\text { (Own analysis) }\end{array}$ \\
\hline
\end{tabular}

Source: own study.

\section{Favorable conditions}

Qualitative research results

Most respondents stated that filling in the grant application itself was not complicated (10 out of 12 people), only paying attention to many appendices and sometimes poor communication systems was. In two cases, the application was completed by the installation company. The respondents also had no significant problems finding an installation company, most often recommended by their friends (seven cases). Everyone gave a "good" and "very good" opinion of the companies that installed the panels for them. More controversy was aroused in terms of the grant waiting time. It amounted to less than four months on average among those who had already received it. In only two cases did it not exceed a month; in two cases, it was two months, and in as many as five cases, it was six months. Two people have not yet received a grant. The time was extended due to the higher number of applications (Table 5).

Table 5. Conditions favoring the investment $(n=12)$.

\begin{tabular}{lc}
\hline \multicolumn{1}{c}{ Favorable Conditions } & Rating \\
\hline $\begin{array}{l}\text { Completing the grant application } \\
\text { Ease of finding a contractor }\end{array}$ & Not difficult or completed by the company \\
Contractor assessment & High (recommended by a friend) \\
$\begin{array}{l}\text { Satisfaction with the way the grant application } \\
\text { is handled }\end{array}$ & Good/very good \\
Source: own study. & (if longer: impatient)
\end{tabular}
Source: own study.

\section{Quantitative research results}

When analyzing the survey (Figure 6), it was found that the majority $(60 \%)$ of the respondents stated that filling in the grant application from the My Electricity program was not complicated and did not require the help of other people. However, the grant application form of $32 \%$ of respondents was filled in by better-informed people, while in $9 \%$ of cases, the owners of the installations were late or were unable to find the application.

\section{Operation}

\section{Qualitative research results}

The My Electricity program's average rating (scale of 1-5) was 4.18 (these responses were obtained from 11 respondents). As an argument for lowering the rating, the following were mentioned: too long a waiting time for a grant, the amount of funding-which, in practice (for large installations), comes down to an amount instead of a percentageand communication problems (Table 6). At the same time, most of the ratings were not lower than 4; only one person assessed the program as "terrible and poorly managed" (this resulted in a relatively high value of the coefficient of variation: $26 \%$; without this extreme assessment, for other users it was $10 \%$ ). One person avoided giving a rating. On the other hand, when assessing the functioning of the PV installation itself, a high degree of 
compliance was obtained (the coefficient of variation was less than $10 \%$ ), with an average of 4.73 (11 people). One person avoided it, not having complete data yet (the time to install the panels did not allow conclusions to be drawn). The dominant ratings were 5 (seven respondents), and the lowest was 4 (two people).

\section{Filling out the application and fasteners for a subsidy for the installation was}

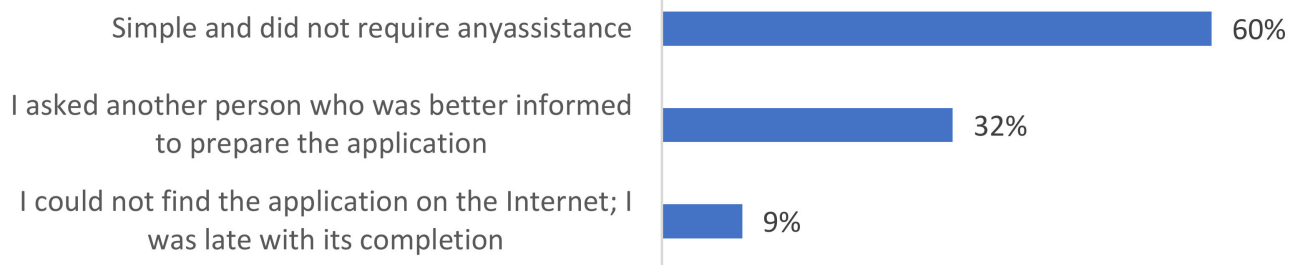

Figure 6. Answers to questions about the difficulty of completing the subsidy form $(n=57)$. Source: own study.

Table 6. Assessment of the operation of PV micro-installations $(n=12)$.

\begin{tabular}{lc}
\hline \multicolumn{1}{c}{ Operation } & Assessment \\
\hline My Electricity program & $\begin{array}{c}\text { Most of the respondents are satisfied with the } \\
\text { program (average grade: } 4.18) ; \text { only one } \\
\text { respondent expressed a negative opinion (due } \\
\text { to the long waiting time for the subsidy) }\end{array}$ \\
\hline Functioning of PV installations & $\begin{array}{c}\text { Most of the respondents are satisfied with the } \\
\text { PV installation (average grade: } 4.73)\end{array}$ \\
\hline PV system technology & $\begin{array}{c}7 \text { respondents assessed the technology very } \\
\text { positively, } 2 \text { respondents underlined the high } \\
\text { cost of installation, } 2 \text { respondents forecasted } \\
\text { the development of other energy technologies, } \\
\text { 1 respondent did not see the development of } \\
\text { PV technology without simultaneous } \\
\text { investments in energy storage. }\end{array}$ \\
\hline
\end{tabular}

Source: own study.

Regarding the PV technology itself, the assessments turned out to be more varied. Seven people had positive thoughts about this technology, assessing it very highly as good, engaging, and even excellent and fantastic, the highest compared to other technologies. It was also noted that it would be constantly improved. Two people were less decisive in their opinion; on the one hand, they considered clean energy harmless to health and on the other, they pointed to the costly nature of such an installation. Some people (two respondents) claimed that this is not the future of technology and that other energy sources (such as nuclear or wind power plants) will have a more significant market share than PV systems in the future. An essential aspect of the respondents' statements was building home energy storage. Technology without storage batteries is uncontrollable, and so it was even described as a "crazy and an exclusive idea" (one person).

Quantitative research results

When analyzing the survey, the average level of satisfaction with the level of dotation amounted to 2.9, with the coefficient of variation equal to $46 \%$ (Figure 7 ). Although it was found that there was no relationship between the satisfaction with the amount of the subsidy and the size of the micro-installation (Mann-Whitney test: $p>0.05$ ), the research on a larger scale could give different answers. The limit was $6 \mathrm{~kW}$, as only $3.5 \%$ of the installations were in the range of $2-3 \mathrm{~kW}$ (with the highly valued amount of co-financing; 
one person could not answer the question about the size of the installation and gave the lowest score).

\section{The level of satisfaction with the dotation}

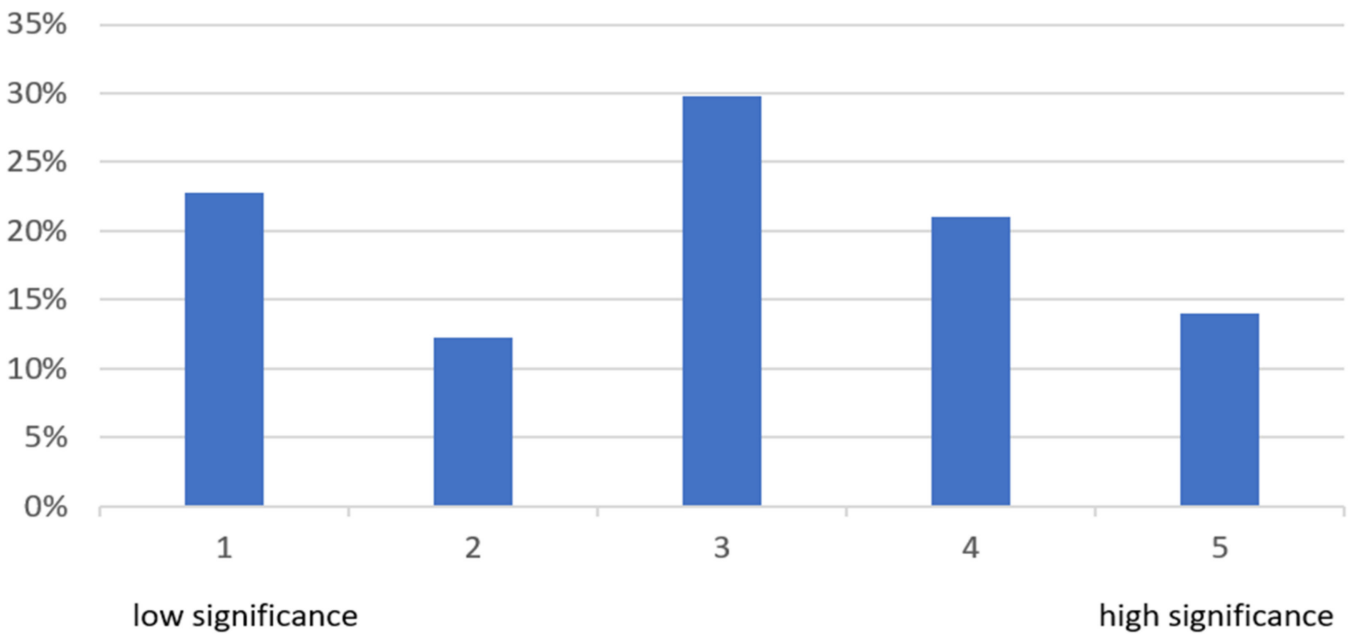

Figure 7. Satisfaction with the subsidy level $(n=57)$. Source: own study.

Despite moderate assessments of the subsidy amount, the respondents assessed it positively when assessing the My Electricity program itself. They were asked to comment on the five sentences in Figure 8. As many as $72 \%$ of the respondents agreed that it is a very well-suited support program that increases the production of green energy. On the other hand, $35 \%$ of respondents claimed that the program is good but has a complicated way of obtaining a subsidy ( $54 \%$ were against). Forty-six percent of people confirmed that the program made no difference to their decision; it would have been made regardless of the program (this could indicate that it was also another motivating factor). It is noteworthy that the same number of respondents disagreed with this statement. On the other hand, the opinion that the program is unnecessary and that homeowners themselves should finance investments in energy production for their needs was not agreed to by as many as $86 \%$ of the respondents. They also opposed the opinion (84\%) that the co-financing of investments in PV is a wasted public fund and that the residents of blocks do not have such a possibility.

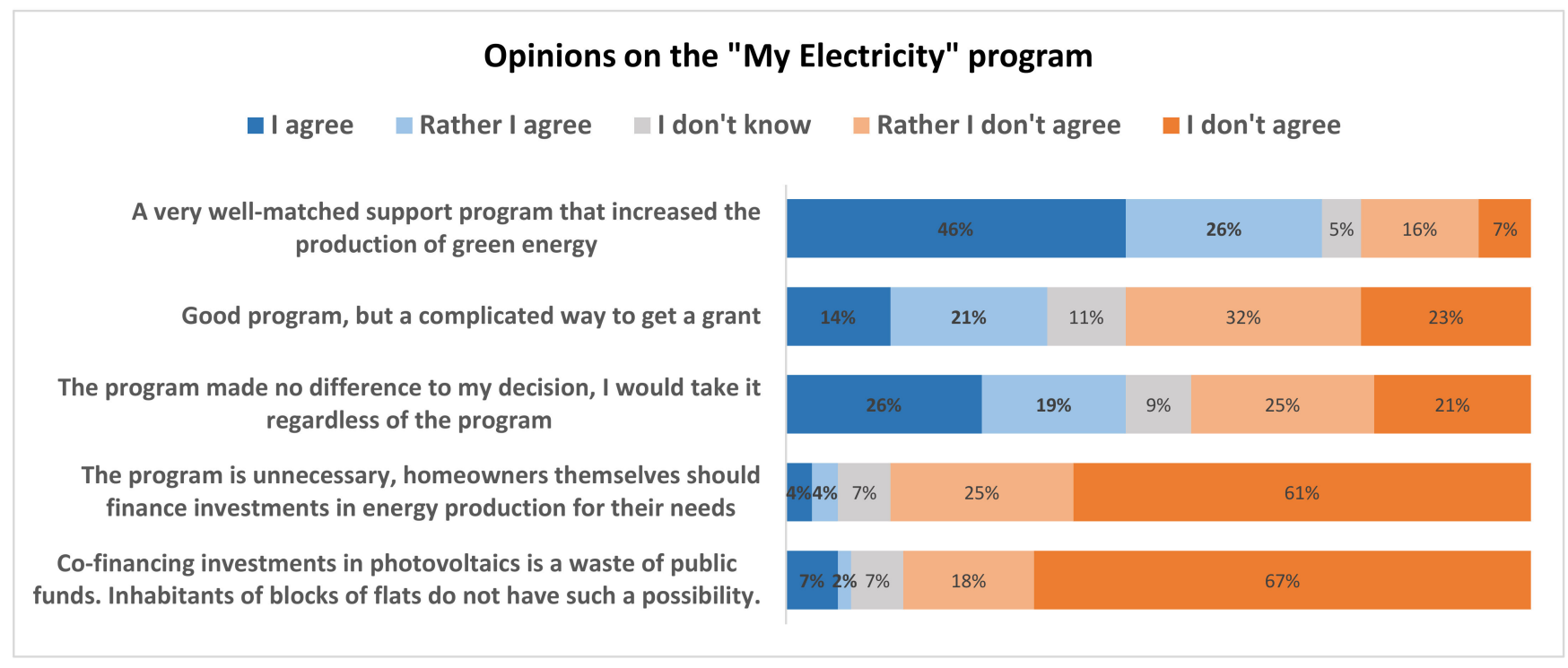

Figure 8. Viewpoints on the My Electricity program $(n=57)$. Source: own study. 


\subsection{Skepticism towards PV Micro-Installations}

As a result of interviews with skeptics of PV micro-installations, three groups of concerns preventing the investment decision were identified (Table 7).

Table 7. Reasons for skepticism towards PV micro-installations $(n=7)$.

\section{Concerns}

Group of Factors

Too high investment cost and too little grant amounts

Uncertainty of the return on investment and the risk of additional costs

The prospect of ending the net metering system and switching to a

Finances

purchase and sale system

No preparation of the Polish power grid

Pushing outdated technological ideas out

Risk of careless installation

Technology

Risk of problems with servicing the installation in the future

\begin{tabular}{lc}
\hline Aggressive marketing of traders of companies installing home PV systems & Social relations \\
\hline Fire hazards & Energy \\
\hline The problem with disposal after the PV installation becomes unusable & Ecology \\
\hline
\end{tabular}

Source: own study.

The first group was about finance. The respondents believed that the investment cost was too high and continually increasing and that the grants were too small. They would expect a $50 \%$ return on their investment. Meanwhile, they noticed a decrease in grant amounts (the My Electricity program, as an example, which reduced grants from PLN 5000 (1085 EUR) to 3000 (651 EUR) in the 3.0 edition). Moreover, they pointed to the uncertainty of the return on investment and the risk of additional costs. Concerns resulted from the information on removing the discount system and proposals to install expensive home energy storage.

The second group of concerns was related to technology. Respondents pointed to the lack of preparation of Polish power grids. These concerns resulted from the information that the power grid is unprepared for bidirectional operation, which will disconnect the installation from the grid due to a voltage build-up and will result in losses for investors in the form of a lack of electricity production. In addition, respondents were concerned about outdated technological ideas being pushed out to Poland. Concerns resulted from circulating information that used installation parts are imported from Western countries and that, therefore, they will break down quickly and be a problem. They prefer to wait for the advancement of technology. Additionally, the respondents pointed to the risk with servicing. They believed that the booming interest in PV system installations was caused by the aggressive marketing of installation companies, encouraging them to invest in home PV systems. They are also warned about such practices from publications on the Internet [47]. Many fast-growing installation companies raise concerns about wanting to achieve short-term profits and disappearing from the market quickly, although they guarantee several years for the installed installations. In this case, it will not be possible to service the installation and make claims if it starts to break down over some time or because of weather factors.

The last group of concerns included safety and, more precisely, the fire hazard resulting from PV micro-installations. They were caused by information about (1) cases of unprofessional installation, (2) cases of saving on components to reduce installation costs, and (3) lack of a formalized system of supervision over installations.

\subsection{Balancing Enthusiasm and Skepticism-Expert Opinions}

The expansion of PV micro-installations and the stability of the power system

The first issue in the expert interviews was the expansion of PV micro-installations. The interviews revealed the fact that, according to the PEP2040, the national system should be completely rebuilt between 2021 and 2040. The capacity foreseen for PV systems in 2040 
should amount to 10 or even 16 GW. However, there are projections that this could be 15 GW of capacity in 2025. Nevertheless, according to experts, the rapid growth of PV systems recently has exceeded all previous predictions, which is both a valuable and expected phenomenon in terms of environmental protection. In 2020, approximately 300,000 PV micro-installations (up to $50 \mathrm{~kW}$ ) with a capacity of nearly $2 \mathrm{GW}$ were connected to the distribution network. That represented an increase of roughly $200 \%$ in both the number of installations and the total capacity (from $1 \mathrm{GW} / 155000$ to $3 \mathrm{GW} / 457000$ ). The announcement of a change in the rules for introducing electricity to the grid and using it outside the working hours of the PV installation, consisting in moving away from net metering and towards the purchase and sale principle, will most likely accelerate the investment decisions of Polish society regarding PV micro-installations in 2021. Instead of the current net metering, i.e., the right to an annual settlement of the balance of energy fed into the grid, reduced by $20 \%$ or $30 \%$ and used, the principle of selling energy fed into the grid to an aggregator or ex officio seller, at market price, announced by the President of the ERO will be introduced. In hours outside of the operation of the PV installation, the energy would be purchased at the tariff/contract price. Therefore, the proposed changes in the principles of prosumers' settlement may reduce the effectiveness of investments in household sources and inhibit the growth of new installations after 2021.

In addition, experts pointed out that the increase in investments in PV micro-installations impacts the stability and management of the national power system, as the energy introduced by them into the system cannot be regulated or stored. Therefore, there is a requirement for the existence of other, regulated sources, the power of which can be flexibly varied. Currently, in the national system, the regulatory power is provided by centrally dispatched coal facilities, and over time their functions will be taken over by gas plants and energy storage. The following energy storage solutions could be proposed for PV micro-installations tailored to the needs of prosumers and large-scale micro-installations. In the case of a tailor-made installation, presented in Figure 9, to balance energy production and its use, it would be necessary to store energy in a seasonal storage battery (the surplus of energy produced in summer would be used in winter). Tailor-made installations could be equipped with short-term energy storage (e.g., lithium-ion batteries), along with a storage management program (charging in maximum sunlight, powering home appliances in the morning and evening peak times).

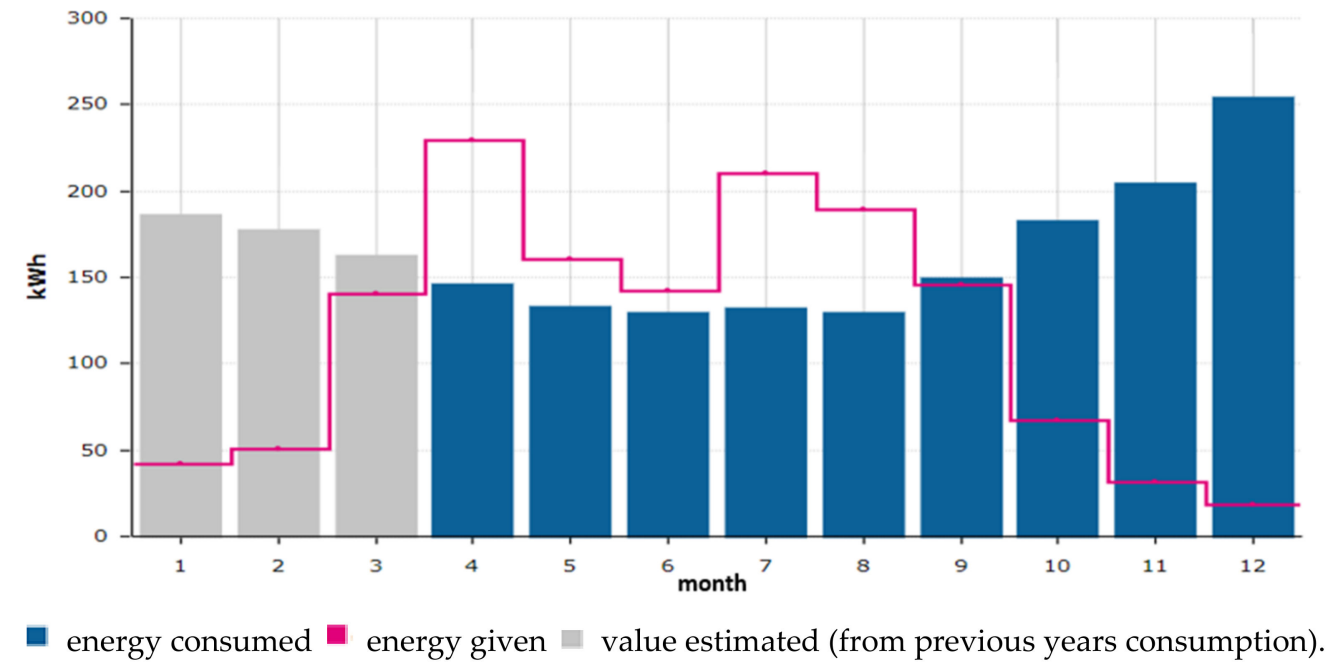

Figure 9. Diagram of energy consumed and fed into the grid from a home installation adjusted to the demand in 2020. Source: own study.

In the case of large-scale installations (Figure 10), the energy used for heating in winter, using the net metering principle or, occasionally, seasonal or daily storage, would also be beneficial. In this case, a disadvantageous phenomenon is "boosting" the voltage in low-voltage networks during hours of maximum sunlight, installation shutdown, and the 
possibility of damage to home electronic equipment sensitive to rising voltages. Therefore, large-scale installations, where the energy consumption is not in the same profile, used seasonally have a more negative impact on the stability and safety of the power system operation. They cause excessive energy production during the period outside of home use, the risk of "boosting" the voltage in the local low-voltage grid, the risk of damage to home electronic equipment, and the risk of shutting down the installation after overvoltage protection is triggered. In the case of large-scale installations, short-term storage does not solve the above problems. In this case, seasonal storage (e.g., electrolyze-tank-hydrogen cell) would be necessary together with an energy management system. Such solutions are currently available but expensive.

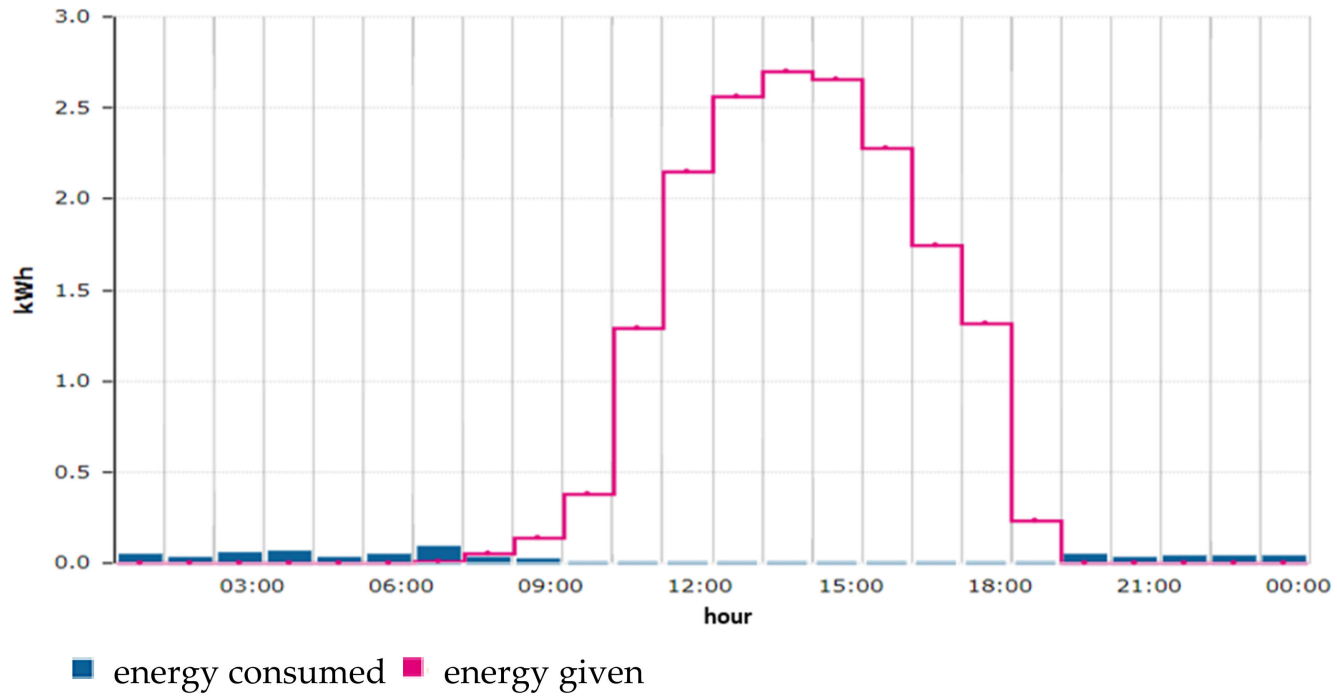

Figure 10. Graph of energy used and fed into the network during the day from a large-scale installation. Source: own study.

The above risks, both for tailor-made and large-scale installations, can be partially resolved by modernizing and automating the operation of medium- and low-voltage networks, notably, by regulating the voltage at transformer stations and the possibility of controlling the operation of prosumer installations (including the possibility of disconnecting or limiting the power). In addition, low- and medium-voltage power stations to which PV sources of various powers are connected should be equipped with energy storage batteries, matched to the size of the sources.

Due to the policy of decarbonization and increasing the use of renewable energy for heating and transport purposes, one should expect a systematic increase in the capacity of renewable installations integrated with energy storage, heat pumps, and electric car charging points. Management systems of home energy grids will be necessary for these needs. However, further development of PV installations, integrated with local energy storage and management, is possible together with progress in modernizing medium- and low-voltage grids and matching energy use profiles with their local production. Larger systems will require changes in legal regulations that will allow local operators to control the operation of these installations.

\section{Safety of PV micro-installations}

The second issue raised during the interviews was the safety of PV micro-installations. It was tested in several risk areas. The first was careless installation. Experts rated the risk of negligent installation as medium-high, as on a scale of 1 to 10 their average rating was 6 , with a compliance rate of $27 \%$. This risk should be considered in the components' quality, particularly the quality of dismantled panels imported into the country. The quality of components and the assembly method of micro-installations are critical issues for their safety. Unfortunately, according to experts, the system for supervising the knowledge and skills of people who carry out PV installations is deficient, and a quality control 
system for PV micro-installations does not exist. Usually, installation companies propose components to the investor. However, they are not checked for being selected correctly, nor is it checked whether the proposed components are really installed. Since only the installation report is sent to the energy distributor, the energy system operator cannot interfere with the installation. Usually, periodic inspections of the installation by the companies that carried them out are not performed either. Therefore, according to experts, a system of authorizations for fitters and a system of ad hoc (randomly selected) inspections for PV installations should be introduced. Then, even before connecting to the energy system, incorrectly carried out installations could be eliminated.

The second discussed area of the safety risk of PV micro-installations was the risk of overheating and fire. Experts assessed this risk as relatively low, as their average rating was 2.25 (on a scale from 1 -low risk to 5 -high risk). When analyzing the mentioned risk, attention should primarily be paid to the issue of cables placed on hot roofs. The problem arises when the PV micro-installation is improperly made, and the spaces between the roof and the panels are too small; then, roofs reaching high temperatures can lead to fires of electric cables. In addition, loose and hanging wires can be damaged by sliding snow. When assembling the installation, it should be ensured that the cables do not hang loose and do not have contact with the roof, i.e., they are carefully tied to the supporting structure of PV panels. According to the trade press [48], the most common cause of fires is improper connections between modules, i.e., mainly poor quality of MC4 connectors. If these connectors become hot, they can cause an electrical arc and fire. It should also be made sure that the connectors are compatible, i.e., they do not come from different manufacturers. Unfortunately, some panel brands do not guarantee the quality of MC4 connectors. Since 2020, Poland has required micro-installation projects with a capacity exceeding $6.5 \mathrm{kWp}$ to be agreed upon with a fire protection expert. Proper positioning of the inverter is also essential for fire protection. An adequate distance from walls and ceilings must be provided to ensure cooling. It cannot be installed on a flammable material, such as wooden beams or paneling, and if it is impossible due to the house's structure, then an appropriate insulating plate should be attached behind the inverter.

The third examined risk area was the risk of overvoltage and damage to electrical equipment in domestic installations. Experts assessed this risk as low, as their average rating was 3 (on a scale from 1 -low risk to 5 -high risk). Nominal, single-phase voltage in a home installation should be $230 \mathrm{~V}$. As a result of the operation of the micro-installation during hours of intense sunlight, the voltage may increase above this value. The inverters have voltage limiters, set at $250-255 \mathrm{~V}$, which disconnect the power supply in the event of exceeding the limit value, thus protecting household appliances against damage due to undesirable voltage surges.

The fourth discussed area was the weather risk, i.e., storms, hail, strong wind, torrential rain, snow. Experts also assessed this risk as low, as their average rating was 2 (on a scale from 1-low risk to 5-high risk).

\section{Obligation to install a PV micro-installation}

Another issue examined during the interviews was the probability of introducing the obligation to install PV installations in new facilities in Poland. Experts rated it as less than $20 \%$. However, they did point out a few limitations. The first is related to the fact that not every new facility will have conditions sunny enough for installing a PV micro-installation (e.g., near a forest) and that there would be no point in carrying out a PV installation for such facilities. Regulations should, therefore, take such cases into account. In addition, before introducing such a regulation, grid constraints should be resolved so that the newly created facility is not located where the power grid cannot accept the energy produced by the PV installation. It is also worth adding that future "passive houses" may be independent of the grid or only connected for reserves in emergency conditions. Experts also predict that PV system technology may be heading towards producing particular components (e.g., tiles or windows) that will function as the current PV panels. What also 
may happen is that investors will be unable to accept the risk of fire or the additional costs of investing in PV systems, such that they will object to this obligation.

\section{Disposal of PV panels}

During the interviews, the issue of panel disposal was also investigated. It is closely related to resource conservation and the circular economy. Experts concluded that at the time of sale of the panels, solutions related to the Extended Producer Responsibility (EPR) should be proposed, which would oblige them to manage used panels or deposit a specific amount in an appropriate fund dedicated to the disposal of panels. Experts also admitted that a scenario is possible where a part of the society using PV panels will not dismantle them but keep them on their roofs despite their lack of efficiency. However, experts indicate that clear legal regulations and the commercial effectiveness of technological solutions for processing used panels are crucial for the disposal of PV panels. According to experts, it is inevitable that technologies dealing with the removal of PV panels will be developed. That can also be confirmed by researchers from Krakow AGH University of Science and Technology and 2loop Tech SA, who have just developed a technology that allows the recovery of raw materials from currently used PV panels. Experts, therefore, assessed the risk of dumping PV panels as 4 (on a scale from 1 to 10). On the other hand, they estimated the chances of new technologies emerging that recycle PV panels at 6.

\section{State support for the development of PV micro-installations}

According to experts, the state should subsidize the development of home PV systems for as long as necessary to ensure a controlled expansion of this type of energy production. That may mean, to start with, only grants for PV micro-installations that produce energy intended for direct self-consumption (such as heat pumps) or for storage and self-consumption time-shifting. However, they pointed out that the development of this technology should ultimately be based on an economic calculation.

\section{Discussion of Findings}

To answer the first research question, "What is the assessment of the effectiveness of the My Electricity program in terms of increasing the production of renewable energy in prosumer sources from the perspective of the beneficiaries, business, and the local community?", it was found that the beneficiaries assessed the studied program quite well. The owners of small PV installations consider the grant offered by the program as a good motivation. On the other hand, owners of larger PV installations prefer the subsidy to be established as a percentage rather than an amount. In all examined cases, the possibility of tax relief was also looked upon favorably. The surveyed prosumers described the financial effort put into the investment as medium or medium-high. They also favorably assessed the interactions with companies installing home PV systems and the process of handling the application for grants, although, in terms of communication, they would have expected more user-friendly solutions. Participants in the online survey confirmed the conclusions drawn from the interviews. Thus, quantitative research confirmed the dominance of economic motives over ecological ones. Likewise, the most common option selected for the potential use of electricity from PV systems was the possibility of charging batteries and storing energy. In turn, skeptics of PV micro-installations rated the financial effort in this type of investment as decidedly high, and traders installing home PV systems were described as intrusive and discouraging when interacting, nor were they convinced by the prospect of increasing electricity prices in Poland. The research results are consistent with the works examining the phenomenon of the acceptance of green technologies in energy. The work of [20,28-33], just like the research results presented in this article, point out the importance of grants and tax relief as well as a quick return on investment. However, the work of [28] points out that the decision to invest also depends on income, education, age, and knowledge about green technologies. Moreover, as described in study [47], various social and individual factors influence the willingness to install PV systems. Thus, according to [45], unique characteristics, such as personality, environmental and personal values, and technical and financial attitudes, can influence the decision as to whether a PV system will 
be installed. That may explain why the same factors that turned out to be motivating for the studied prosumer cases were not encouraging for skeptics of PV micro-installations. The presented research results are also consistent with the results described in the work of [32], in terms of the benefits of being a prosumer, but differ slightly from the concerns related to micro-installations. Compared to the results of the work of [32], the research described in this article shows a broader perspective of concerns associated with the technical and safety aspects of micro-installations. Most likely, these differences are related to the passage of time and, thus, the different knowledge of Polish society about PV systems.

In the context of answers to the second research question, "In what directions should the My Electricity program be modified?", it is worth noting that the analysis of interviews with supporters and objectors of PV micro-installations showed that the grant, in the opinion of the former, should depend on the size of the investment and, in the opinion of the latter, that the grants should cover $80-90 \%$ of the investment. (Among the respondents using the online questionnaire, the distribution of satisfaction with the received subsidy turned out to be symmetrical, with an average level of 2.9 and the coefficient of variation equal to $46 \%$.) Opposing such expectations are experts, especially from the energy industry. They are concerned about the rapid growth of prosumer PV installations. They argued that the present, very favorable conditions for investors in such installations cause their uncontrolled growth, which may threaten the stability of the national energy system. Such divergent positions regarding the growth rate of PV installations are reflected in the results of other researchers. For example, the research results of $[20,21]$ indicate that the main factors motivating pro-ecological behavior are economic factors, which would explain the high expectations regarding grants, especially by skeptics of this type of investment. In turn, the viewpoint of energy industry experts can be explained by the energy system problems experienced by other countries, e.g., Croatia [15], and similar topics were also discussed in the work of [16]. Therefore, experts from the energy industry are calling for legal regulations to inhibit the uncontrolled growth of PV micro-installations and the need for time to carry out appropriate investments within the grid. The results describing the experts' viewpoint are consistent with the results of other researchers. There are publications available that propose solutions to modernize the national grid for the needs of PV micro-installations. [17,18]. For example, [17] analyzes the case in which a rural line with connected PV installations in northern Poland, reducing the line resistance by replacing power lines with ones with a larger cross-sectional area, effectively reduces voltage fluctuations in the network. In turn, the work of [18] analyzes the case of the development of energy cooperatives in rural areas which use the energy produced in the cooperative for their own needs. However, it should be noted that in the event of disturbances (e.g., line overload, excessive voltage increase) caused by the operation of micro-installations, distribution system operators should be legally able to limit this operation (redispatch) and, where possible, obtain flexibility services (e.g., changes in the consumption and generation profile). It relates to the necessity to enforce the provisions of the Network Codes (EU regulation) and the Polish Distribution Grid Code in the scope of the functioning of micro-installations (e.g., parameters of the inverter protection settings). Additionally, the standard connection procedure should be introduced for new installations (as opposed to the previous notifications). These possibilities will help ensure the safety of network users (consumers, prosumers, employees working in the network) and the security of the network and the equipment connected to it. Research on the phenomenon of subsidizing certain market behaviors dedicated to ecology and then gradually withdrawing them is being undertaken all around the world. The economic analyses of solutions for the gradual withdrawal of subsidizing PV micro-installations [34] show that, although the rate of return of this type of investment increases, it is still economically profitable.

Answering the third research question, "How is PV technology perceived in terms of the safety of its users and its impact on the environment?", it was found that, although in all of the studied cases (and, in quantitative research, in 79\% of responses) the process of a home PV installation was described as professional, there were opinions among skeptics 
that this type of installation could cause a fire. Although the experts found that the fire risk is minimal with a correctly carried-out installation, they also concluded that this risk is medium-high with an incorrectly carried-out installation. According to experts, the situation is worsened, because there is currently no proper system for controlling the quality of PV micro-installations in Poland. Therefore, they indicate that regulations in this area are one of the most desirable changes. As far as the impact of PV micro-installations on the environment is concerned, the surveyed prosumers describe the PV technology as very environmentally friendly. In their opinion, they mainly compare it to the coal-based technology that currently dominates in Poland. Primarily, they pay attention to the lack of harmful substance emissions into the atmosphere. However, when asked about the disposal of used PV panels, they admitted that they did not consider this issue when conducting micro-installations. Nevertheless, the surveyed prosumers expressed that the issue of panel disposal is one they intend to deal with in 20 years. In their opinion, technologies and companies will have been created that will solve the problem of this waste commercially by that time. Interviews with experts and the trade press confirmed that the probability of commercial solutions for the disposal of PV panels is relatively high.

\subsection{Implication for Research and Practice}

The implications of this work for science are related to demonstrating the effectiveness of the research method used to assess the My Electricity program. Qualitative and quantitative methods based on a case study of installed PV microsystems, interviews, and surveys with various program stakeholders were used. That allowed exploring the factors determining the decision to install a home photovoltaic system in Polish conditions and the limitations that the Polish energy system must overcome to let prosumer PV micro-installations become part of it. The result of the research is also the conclusion that the proposed research method should be developed in such a way as to combine it with expanded quantitative methods.

The implications for the practice are related to the conclusion that the preparation of the subsequent editions of the My Electricity program should be preceded by a research process that would fully prepare this program for implementation. Carrying out the research process will allow for program improvement in the technical, organizational, and socioeconomic spheres.

Moreover, the implication of the research for practice is the conclusion that conducting assessments of this type makes it possible to measure the support system for the development of home PV systems concerning the expected effects. At the current research stage, it should be stated that, although obtaining electricity from renewable energy sources is highly desirable, subsequent editions of the My Electricity program should be preceded by operations and investments aimed at adapting the Polish energy system to it, such that the connection of further PV micro-installations does not disrupt its efficient operation.

\subsection{Limitation}

The limitation of the research is the short time scope of the program. The My Electricity program has only been running for two years, and the home PV technology itself is still at an early stage of implementation by Polish society. Due to these conditions, a more comprehensive array of research is currently unavailable. It should also be added that contact with the beneficiaries of the My Electricity program is quite difficult, because, apart from the government program for supporting PV micro-installations, there are also many municipal programs. That is why the authors of the article asked the National Fund for Environmental Protection and Water Management for help in contacting the beneficiaries of the Program, as this fund manages it. Quantitative research on a large scale may be carried out as soon as such support is received. 
Supplementary Materials: The following supporting information can be downloaded at: https: / / www.mdpi.com/article/10.3390/en15030846/s1, Table S1: Quantitative survey data.

Author Contributions: Conceptualization, I.Z., S.T., A.M. and M.T.; methodology, I.Z., S.T., A.M. and M.T.; formal analysis, I.Z. and A.M., investigation, I.Z. and A.M.; writing-original draft preparation, I.Z., S.T., A.M. and M.T.; writing-review and editing, I.Z., S.T., A.M. and M.T. All authors have read and agreed to the published version of the manuscript.

Funding: This paper was published as part of statutory research at the Silesian University of Technology, Faculty of Organization and Management, grant number: 13/010/BK_22/0065.

Institutional Review Board Statement: The study was conducted in accordance with the ethics regulations of the Silesian University of Technology. "Ordinance on the establishment and rules of operation of the Commission on Ethics in Research Involving Human Subjects". It implements ordinance No 107/2021 of the Rector of the Silesian University of Technology from 29 June 2021.

Informed Consent Statement: Informed consent was obtained from all subjects involved in the study.

Data Availability Statement: The Supplementary Materials include quantitive research data (Data_research.xlsx).

Conflicts of Interest: The authors declare no conflict of interest.

\section{References}

1. GOV. Available online: https://www.gov.pl/web/klimat/polityka-energetyczna-polski (accessed on 27 August 2021).

2. Turek, M. Walka Ze Smogiem. Koncepcja Opracowania Ogólnokrajowego Programu Likwidacji Niskiej Emisji. Przem. Chem. 2017, 1, 100-103. [CrossRef]

3. Turek, M.; Antos, M. Główny Instytut Górnictwa. In Niska Emisja-Węgiel Tak, Smog Nie: Praca Zbiorowa; Główny Instytut Górnictwa: Katowice, Poland, 2018; ISBN 978-83-65503-15-2.

4. Gruchelski, M.; Garbicz, M. Oficyna Wydawnicza Aspra-JR. In Sektor Prywatny a Sektor Publiczny: Ujęcie Interdyscyplinarne; Oficyna Wydawnicza ASPRA-JR: Warszawa, Poland, 2020; ISBN 978-83-8209-018-5.

5. Gaj, K.; Miller, U.; Sówka, I. Progressing Climate Changes and Deteriorating Air Quality as One of the Biggest Challenges of Sustainable Development of the Present Decade in Poland. Sustainability 2020, 12, 6367. [CrossRef]

6. Jacobson, M.Z.; Delucchi, M.A.; Bauer, Z.A.F.; Goodman, S.C.; Chapman, W.E.; Cameron, M.A.; Bozonnat, C.; Chobadi, L.; Clonts, H.A.; Enevoldsen, P.; et al. 100\% Clean and Renewable Wind, Water, and Sunlight All-Sector Energy Roadmaps for 139 Countries of the World. Joule 2017, 1, 108-121. [CrossRef]

7. Sampedro, J.; Arto, I.; González-Eguino, M. Implications of Switching Fossil Fuel Subsidies to Solar: A Case Study for the European Union. Sustainability 2017, 10, 50. [CrossRef]

8. Siudek, A.; Klepacka, A.M.; Florkowski, W.J.; Gradziuk, P. Renewable Energy Utilization in Rural Residential Housing: Economic and Environmental Facets. Energies 2020, 13, 6637. [CrossRef]

9. Fit for 55. Available online: https://www.consilium.europa.eu/en/policies/eu-plan-for-a-green-transition/ (accessed on 8 November 2021).

10. Tokarski, S.; Magdziarczyk, M.; Smoliński, A. Risk Management Scenarios for Investment Program Delays in the Polish Power Industry. Energies 2021, 14, 5210. [CrossRef]

11. Olczak, P.; Matuszewska, D.; Kryzia, D. "Mój Prąd” as an Example of the Photovoltaic One off Grant Program in Poland. Polityka Energ. Energy Policy J. 2020, 23, 123-138. [CrossRef]

12. Olczak, P.; Olek, M.; Matuszewska, D.; Dyczko, A.; Mania, T. Monofacial and Bifacial Micro PV Installation as Element of Energy Transition-The Case of Poland. Energies 2021, 14, 499. [CrossRef]

13. NFOŚiGW Program. "Mój Prąd"—Założenia Szczegółowe. Available online: https://www.gov.pl/web/nfosigw/program-mojprad--zalozenia-szczegolowe (accessed on 8 November 2021).

14. NFOŚiGW: Ponad 110 Tysięcy Wniosków o Dotację Na Fotowoltaikę w Trzeciej Edycji Programu "Mój Prąd"; Alokacja Drugiej Edycji Programu Na Wyczerpaniu. Available online: https://www.gov.pl/web/nfosigw/nfosigw-ponad-110-tysiecy-wnioskowo-dotacje-na-fotowoltaike-w-trzeciej-edycji-programu-moj-prad-alokacja-drugiej-edycji-programu-na-wyczerpaniu (accessed on 8 November 2021).

15. Budin, L.; Grdenić, G.; Delimar, M. A Quadratically Constrained Optimization Problem for Determining the Optimal Nominal Power of a PV System in Net-Metering Model: A Case Study for Croatia. Energies 2021, 14, 1746. [CrossRef]

16. Zaręskki, P.; Krupin, V.; Zwęglińska-Gałecka, D. Renewable Energy Generation Gaps in Poland: The Role of Regional Innovation Systems and Knowledge Transfer. Energies 2021, 14, 2935. [CrossRef]

17. Szultka, A.; Szultka, S.; Czapp, S.; Zajczyk, R. Voltage Variations and Their Reduction in a Rural Low-Voltage Network with PV Sources of Energy. Electronics 2021, 10, 1620. [CrossRef] 
18. Jasiński, J.; Kozakiewicz, M.; Sołtysik, M. Determinants of Energy Cooperatives' Development in Rural Areas-Evidence from Poland. Energies 2021, 14, 319. [CrossRef]

19. Ruf, H. Limitations for the Feed-in Power of Residential Photovoltaic Systems in Germany-An Overview of the Regulatory Framework. Sol. Energy 2018, 159, 588-600. [CrossRef]

20. Parzonko, A.J.; Balińska, A.; Sieczko, A. Pro-Environmental Behaviors of Generation Z in the Context of the Concept of Homo Socio-Oeconomicus. Energies 2021, 14, 1597. [CrossRef]

21. Faiers, A.; Neame, C. Consumer Attitudes towards Domestic Solar Power Systems. Energy Policy 2006, 34, 1797-1806. [CrossRef]

22. Briguglio, M.; Formosa, G. When Households Go Solar: Determinants of Uptake of a Photovoltaic Scheme and Policy Insights. Energy Policy 2017, 108, 154-162. [CrossRef]

23. Müller, S.; Rode, J. The Adoption of Photovoltaic Systems in Wiesbaden, Germany. Econ. Innov. New Technol. 2013, 22, 519-535. [CrossRef]

24. Zhang, Y.; Song, J.; Hamori, S. Impact of Subsidy Policies on Diffusion of Photovoltaic Power Generation. Energy Policy 2011, 39, 1958-1964. [CrossRef]

25. Graziano, M.; Gillingham, K. Spatial Patterns of Solar Photovoltaic System Adoption: The Influence of Neighbors and the Built Environment. J. Econ. Geogr. 2015, 15, 815-839. [CrossRef]

26. Müller, J.; Trutnevyte, E. Spatial Projections of Solar PV Installations at Subnational Level: Accuracy Testing of Regression Models. Appl. Energy 2020, 265, 114747. [CrossRef]

27. Best, R.; Burke, P.J.; Nishitateno, S. Evaluating the Effectiveness of Australia's Small-Scale Renewable Energy Scheme for Rooftop Solar. Energy Econ. 2019, 84, 104475. [CrossRef]

28. Kowalska-Pyzalska, A. An Empirical Analysis of Green Electricity Adoption Among Residential Consumers in Poland. Sustainability 2018, 10, 2281. [CrossRef]

29. Lekavičius, V.; Bobinaitè, V.; Galinis, A.; Pažèraitè, A. Distributional Impacts of Investment Subsidies for Residential Energy Technologies. Renew. Sustain. Energy Rev. 2020, 130, 109961. [CrossRef]

30. Nicolini, M.; Tavoni, M. Are Renewable Energy Subsidies Effective? Evidence from Europe. Renew. Sustain. Energy Rev. 2017, 74, 412-423. [CrossRef]

31. Lewandowska, A.; Chodkowska-Miszczuk, J.; Rogatka, K.; Starczewski, T. Smart Energy in a Smart City: Utopia or Reality? Evidence from Poland. Energies 2020, 13, 5795. [CrossRef]

32. Ropuszyńska-Surma, E.; Węglarz, M. Profiling End User of Renewable Energy Sources among Residential Consumers in Poland Sustainability 2018, 10, 4452. [CrossRef]

33. Yang, X.; He, L.; Xia, Y.; Chen, Y. Effect of Government Subsidies on Renewable Energy Investments: The Threshold Effect. Energy Policy 2019, 132, 156-166. [CrossRef]

34. De Doile, G.N.D.; Rotella Junior, P.; Carneiro, P.F.G.; Peruchi, R.S.; Rocha, L.C.S.; Janda, K.; Aquila, G. Economic Feasibility of Photovoltaic Micro-Installations Connected to the Brazilian Distribution Grid in Light of Proposed Changes to Regulations. Energies 2021, 14, 1529. [CrossRef]

35. Doris, E.; Krasko, V.A. Strategic Sequencing for State Distributed PV Policies: A Quantitative Analysis of Policy Impacts and Interactions; National Renewable Energy Laboratory: Washington, DC, USA, 2012. [CrossRef]

36. Ryan, A.J.; Donou-Adonsou, F.; Calkins, L.N. Subsidizing the Sun: The Impact of State Policies on Electricity Generated from Solar Photovoltaic. Econ. Anal. Policy 2019, 63, 1-10. [CrossRef]

37. Bollinger, B.; Gillingham, K. Peer Effects in the Diffusion of Solar Photovoltaic Panels. Mark. Sci. 2012, 31, 900-912. [CrossRef]

38. Davidson, C.; Drury, E.; Lopez, A.; Elmore, R.; Margolis, R. Modeling Photovoltaic Diffusion: An Analysis of Geospatial Datasets. Environ. Res. Lett. 2014, 9, 074009. [CrossRef]

39. Balta-Ozkan, N.; Yildirim, J.; Connor, P.M. Regional Distribution of Photovoltaic Deployment in the UK and Its Determinants: A Spatial Econometric Approach. Energy Econ. 2015, 51, 417-429. [CrossRef]

40. Schaffer, A.J.; Brun, S. Beyond the Sun-Socioeconomic Drivers of the Adoption of Small-Scale Photovoltaic Installations in Germany. Energy Res. Soc. Sci. 2015, 10, 220-227. [CrossRef]

41. Sommerfeld, J.; Buys, L.; Mengersen, K.; Vine, D. Influence of Demographic Variables on Uptake of Domestic Solar Photovoltaic Technology. Renew. Sustain. Energy Rev. 2017, 67, 315-323. [CrossRef]

42. Richter, L.-L. Social Effects in the Diffusion of Solar Photovoltaic Technology in the UK; Apollo-University of Cambridge Repository: Cambridge, UK, 2013. [CrossRef]

43. Rode, J.; Weber, A. Does Localized Imitation Drive Technology Adoption? A Case Study on Rooftop Photovoltaic Systems in Germany. J. Environ. Econ. Manag. 2016, 78, 38-48. [CrossRef]

44. Balta-Ozkan, N.; Yildirim, J.; Connor, P.M.; Truckell, I.; Hart, P. Energy Transition at Local Level: Analyzing the Role of Peer Effects and Socio-Economic Factors on UK Solar Photovoltaic Deployment. Energy Policy 2021, 148, 112004. [CrossRef]

45. Alipour, M.; Salim, H.; Stewart, R.A.; Sahin, O. Predictors, Taxonomy of Predictors, and Correlations of Predictors with the Decision Behaviour of Residential Solar Photovoltaics Adoption: A Review. Renew. Sustain. Energy Rev. 2020, 123, 109749. [CrossRef] 
46. Venkatesh, V.; Morris, M.G.; Davis, G.B.; Davis, F.D. Davis User Acceptance of Information Technology: Toward a Unified View. MIS Q. 2003, 27, 425. [CrossRef]

47. Styczyński, J. Zrobieni Na Zielono, Czyli Wszystkie Grzechy Sprzedawców Fotowoltaiki. Available online: https://www. gazetaprawna.pl/magazyn-na-weekend/artykuly/8221715,glowne-grzechy-fotowoltaiki.html (accessed on 8 November 2021).

48. Kołtowski, K. Pożary Instalacji Fotowoltaicznych. Eksperci Radzą Jak Ich Uniknać. Available online: https://gadzetomania.pl/ 62633, pozary-instalacji-fotowoltaicznych-eksperci-radza-jak-ich-uniknac (accessed on 27 August 2021). 